УДК 378.14.035.7

DOI https://doi.org/10.26661/2522-4360-2021-2-30

\title{
СТРУКТУРА ТА ЗМІСТ ФОРМУВАННЯ ТОЛЕРАНТНОСТІ МАЙБУТНІХ ОФІЦЕРІВ НАЦІОНАЛЬНОЇ ГВАРДІЇ УКРАЇНИ У ВІЙСЬКОВИХ ЗАКЛАДАХ ВИЩОЇ ОСВІТИ
}

\author{
Тробюк Н. Ю. \\ викладач кафедри психології та педагогіки \\ Національна академія Національної гвардії України \\ площча Захисників України, 3, Харків, Україна \\ orcid.org/0000-0003-1491-2716 \\ nataliya_trobyuk@ukr.net \\ Зінченко В. П. \\ кандидат педагогічних наук, дочент, \\ доиент кафедри педагогіки та менеджменту освіти \\ Глухівський національний педагогічний університет \\ імені Олександра Довженка \\ вул. Києво-Московська, 24, Глухів, Сумська область, Украӥна \\ orcid.org/0000-0002-2101-903X \\ volod_zin@i.ua
}

\begin{abstract}
Ключові слова: компоненти, рівні, показники, етапи формування толерантності, освітній процес.
\end{abstract}

У статті обгрунтовано актуальність формування толерантності у майбутніх офіцерів Національної гвардії України у вищому військовому навчальному закладі. Визначено структуру толерантності майбутніх офіцерів Національної гвардії України, змодельовано процес ії формування та основні етапи iii формування у вищому військовому навчальному закладі. На основі аналізу змісту компонентів толерантності різних видів діяльності, що характеризують дослідники, орієнтуючись на змістовне наповнення психограми військовослужбовця Національної гвардії України, та анкетування за авторською анкетою «Стан сформованості толерантності офіцера Національної гвардії України» визначено компоненти та критерії структури толерантності майбутнього офіцера Національної гвардії України. Зокрема, визначено когнітивний, емоційно-вольовий та діяльнісний компоненти структури толерантності майбутнього офіцера Національної гвардії України. Вони тісно пов'язані між собою й становлять комплекс когнітивних, емоційних та поведінкових характеристик фахівця. Зазначено, що кожен із них уміщує мотиваційні ознаки професійної самореалізації офіцера Національної гвардії України. На основі цього визначено та схарактеризовано рівні сформованості толерантності майбутніх офіцерів Національної гвардії України (середній, високий, низький).

Формування толерантності майбутніх офіцерів Національної гвардії України запропоновано впроваджувати в освітній процес вищого військового навчального закладу за такими етапами: когнітивним, емоційно-вольовим, діяльнісним. Такі етапи передбачають формування толерантності у процесі вивчення дисциплін гуманітарного характеру, спеціальних дисциплін, у процесі практики та стажування, у процесі позааудиторної діяльності. Зазначені етапи передбачають створення відповідних умов, зокрема створення толерантного освітнього середовища, підготовку викладачів та офіцерів структурних підрозділів до формування толерантності, підготовку якісного навчально-методичного забезпечення. Зазначено, що такі етапи включають проведення аудиторних та позааудиторних освітніх заходів, тренінгів $з$ формування толерантності, що визначаються як цілеспрямований поетапний процес формування професійно важливої якості майбутніх офіцерів Національної гвардії України під час навчання у вищих військових навчальних закладах. 


\title{
CONTENT OF FORMATION OF TOLERANCE OF FUTURE OFFICERS OF THE NATIONAL GUARD OF UKRAINE IN MILITARY INSTITUTIONS OF HIGHER EDUCATION
}

\author{
Trobiuk N. I. \\ Lecturer at the Department of Psychology and Pedagogy \\ National Academy of the National Guard of Ukraine \\ Zakhysnykiv Ukrainy square, 3, Kharkiv, Ukraine \\ orcid.org/0000-0003-1491-2716 \\ nataliya_trobyuk@ukr.net \\ Zinchenko V. P. \\ Candidate of Pedagogical Sciences, Associate Professor, \\ Associate Professor at the Department of Pedagogy and Educational Management \\ Olexandr Dovzhenko Hlukhiv National Pedagogical University \\ Kyievo-Moskovska str., 24, Hlukhiv, Sumy region, Ukraine \\ orcid.org/0000-0002-2101-903X \\ volod_zin@i.ua
}

Key words: components, levels, indicators, stages of tolerance formation, educational process.

\begin{abstract}
The article substantiates the urgency of forming tolerance of future officers of the National Guard of Ukraine in the higher military educational institution. The structure of tolerance of future officers of the National Guard of Ukraine is determined, the process of its formation and the main stages of its formation in the higher military educational institution are modeled. Based on the analysis of the contents of tolerance of different activities, describing researchers, focusing on the content of the psychogram of a serviceman of the National Guard of Ukraine and questionnaire on the author's questionnaire "Status of tolerance of the officer of the National Guard of Ukraine" identified components and criteria of tolerance structure of the future officer of the National Guard of Ukraine, namely: cognitive, emotionally -volitional and activity. The components of tolerance of the future officer of the National Guard of Ukraine are closely interrelated and forms the complex of cognitive, emotional, and behavioral characteristics of professional. It is noted that each of characteristics contains motivational signs of professional self-realization of the officer of the National Guard of Ukraine. Based on this, the levels of tolerance of future officers of the National Guard of Ukraine (medium, high, low) are characterized and determined.

Formation of tolerance of future officers of the National Guard of Ukraine is offered to introduce in educational process of the higher military educational institution at certain stages. They are cognitive, emotionally-volitional, activity. Implemented stages involve the formation of tolerance in the study of humanities; special disciplines; in the process of practice and internship; in the process of extracurricular activities and provide for the creation of appropriate conditions, as: the creation of the tolerant educational environment, training of lecturers and officers of structural units for the formation of tolerance; preparation of highquality educational and methodical support. It is indicated, that the steps include conducting classroom and extracurricular educational programs, training and the formation of tolerance, defined as a purposeful step by step process of formation of professionally important qualities of future officers of the National Guard of Ukraine during their studies in higher military educational institutions.
\end{abstract}

Постановка проблеми. Завдання та функції Національної гвардії України (далі - НГУ) [12] визначають іï тим військовим формуванням, що виступає гарантом соціального спокою та стабільності в суспільстві. Підготовка майбутніх офіцерів НГУ, що регламентується державними актами
$[13 ; 14 ; 15]$, - це складний процес, на який впливає не тільки науково-технічний і соціальний прогрес, а й досконале опанування сучасної бойової техніки, навички та уміння управлінської діяльності, серед яких важливими є вміння встановлювати контакти 3 людьми, вести діалог, створювати 
атмосферу довіри й доброзичливості, надавати допомогу. Від якісної професійної підготовки майбутнього офіцера НГУ, що здійснюється у Національній академії Національної гвардії України (НАНГУ), його потенціалу, професійних знань та навичок, переконань та поглядів, здатності до толерантних взаємовідносин та отримання нового досвіду у світовому просторі залежить ефективність і продуктивність службово-бойової діяльності НГУ. Діяльність військовослужбовця НГУ передбачає його адаптацію до складних і швидко змінюваних бойових та службово-бойових умов служби, здатність до прийняття фізичної і морально-психологічної перенапруги, вільного орієнтування у новому і динамічному соціально-комунікативному просторі та уміння належним чином спілкуватися у професійному середовищі, тому майбутнього офіцера слід ще під час навчання у військовому закладі готувати до такої діяльності, розвиваючи у нього професійно важливі якості, особливе місце серед яких належить толерантності [18; 19]. 3 огляду на це виникає необхідність обгрунтувати процес формування толерантності майбутнього офіцера НГУ у вищому військовому навчальному закладі (ВВН3), що удосконалюватиме формування якісних професійних компетентностей, зокрема виробить вміння бути гнучким, терплячим, доброзичливим, комунікабельним, толерантним і дипломатичним, відкритим до діалогу. Толерантність у системі органів внутрішніх справ допомагає активно освоювати нове середовище i шукати шляхи професійної самореалізації в ньому, успішно контактувати 3 людьми. Саме це $\epsilon$ показником моральної компетентності фахівця [11].

Дослідження поняття професійної підготовки освітнього середовища у своїх працях висвітлюють А. Алексюк, Г. Балл, І. Зязюн, В. Орлов, О. Рудницька, В. Сластьонін та ін. Поняття професійної підготовки військових формуваньдосліджують I. Азаров, А. Аніщенко, Є. Денисенко, В. Желясков, К. Тушко, Д. Швець та ін. У результаті аналізу цих наукових досліджень було встановлено, що толерантність виступає однією з умов професійної підготовки фахівців зазначеної сфери. Так, науковцями $[1 ; 4 ; 6 ; 20]$ толерантність визначається як компонент професійної компетентності майбутніх офіцерів Державної кримінальновиконавчої служби України, як особистісна характеристика природної культури військових, як чинник готовності офіцера Збройних сил України до активної професійної, соціально значущої діяльності у міжнародних операціях 3 підтримання миру i безпеки, як професійно важлива якість діяльності судноводія, як складова частина соціально-комунікативної компетентності військового авіаційного фахівця, як складова частина психо- логічної культури майбутніх офіцерів Збройних сил України. Як бачимо, толерантність стосується базової характеристики міжособистісного спілкування, комунікації, а також проблеми свідомості і поведінки людини в суспільстві. Але, як свідчить аналіз інформаційних джерел, спеціальних досліджень, які б обгрунтували процес формування толерантності майбутніх офіцерів Національної гвардії України, не проводилось.

Отже, мета статті - визначити структуру толерантності майбутніх офіцерів Національної гвардії України, змоделювати процес та основні етапи ii формування у ВВН3.

Виклад основного матеріалу. XXI століття характеризується новими соціальними процесами і подіями, які сприяють розширенню толерантного середовища, проте одночасно провокують різні за своїм характером прояви інтолерантності на грунті територіальної і релігійної роз'єднаності, наявності націоналістичних настроїв, схильності до екстремізму та високої корумпованості. Агресивність, насилля, нетерпимість та конфліктність у людських стосунках сучасного світу зумовили підвищення рівня уваги до питання виховання толерантності особистості. Проблема толерантності торкається усіх сфер суспільного життя держави, зокрема й установ, що впливають на формування моделі поведінки особистості у соціумі. Саме тому особливої значущості набуває проблема формування толерантності як моральної якості особистості, яка характеризується здатністю сприймати без агресії певні іншоcmi. Формування толерантності у системі ВВНЗ $\epsilon$ необхідністю, адже саме ефективна діяльність військових формувань $є$ певним чинником, що впливає на соціальний спокій держави, мирне співіснування, виховання підростаючого покоління та формування соціальних норм. У Декларації принципів толерантності наголошується, що саме політика і програми в галузі освіти повинні сприяти покращанню взаєморозуміння, зміцненню солідарності і толерантності [5]. Завдяки освіті не тільки зберігається стійкість суспільства, але й модифікуються форми й типи взаємин людей, взаємодії культур. Як пріоритетну мету сучасної освіти визначено формування особистості, готової до активної творчої діяльності в сучасному полікультурному і багатонаціональному середовищі, котра зберігає свою соціально-культурну ідентичність, прагне до розуміння інших культур, поважає інші культурно-етнічні спільності, вміє жити в мирі та злагоді 3 представниками різних національностей, рас і вірувань [3].

Безумовно, у ВВНЗ зміст, завдання і функції освітнього процесу мають свої особливості. Відповідно до завдань нашого дослідження нам необхідно з'ясувати, яким чином потрібно органі- 
зовувати освітній процес ВВНЗ для формування толерантності майбутніх офіцерів НГУ. Передумовою ефективності процесу формування толерантності майбутніх офіцерів НГУ в закладах вищої освіти $€$ визначення критеріїв та показників оцінювання толерантності. Аналіз структурних компонентів толерантності має важливе практичне значення, оскільки він дає змогу зрозуміти й ураховувати іiі якісні характеристики, рівні й показники ії прояву та передбачати ефективність iï формування у майбутніх офіцерів НГУ у ВВНЗ.

Розкриваючи досвід експериментального дослідження, М. Монахов визначає критерій як зразок, еталон, що відтворює вищий і досконалий рівень сформованості певного утворення, порівняно 3 яким можна встановити рівень відповідності й наближення ідеального рівня до норм та ідеалу [9].

На думку авторів [7], критерій це - засіб для судження, ознака, на основі якої робиться оцінка, визначення або класифікація чого-небудь; основна ознака, за якою одне рішення обирається із багатьох можливих; мірило судження та оцінки.

Компоненти толерантності досліджуються у багатьох наукових роботах у різних сферах її прояву. Зокрема, зазначене питання досліджували такі вчені: О. Бабчук, О. Брюховецька, І. Галицький, О. Грива, Р. Кострубань, С. Крук, І. Кушніренко, А. Маркарян, А. Молчанова, О. Морозов, М. Мельничук, В. Павленко, А. Ремньова, О. Столяренко, М. Фоміна, С. Хілько, О. Шаюк. Аналіз робіт вказаних науковців дозволяє констатувати відсутність єдиної думки з питання про основні складники толерантності. Нашу увагу привернули роботи науковців, які досліджували проблему виховання толерантності у військовому середовищі, оскільки такі роботи мають для нашого дослідження особливу цінність. Так, А. Маркарян визначає толерантність як інтегральну якість особистості військовослужбовця за призовом та виділяє такі структурні компоненти: раціональний, емоційний та дієво-практичний. Серед критеріїв учений відмічає такі: стійкість, осмисленість, самостійність, наполегливість та характер мислення [8]. Під толерантністю О. Морозов розуміє системну якість особистості, яка структурно складається із трьох основних компонентів, а саме: власне толерантності, інтолерантності і міжособистісної інтолерантності. Власне толерантність зумовлює великий діапазон відмінностей в когнітивних властивостях курсантів і сержантів та відмінностей в особистісних, стильових і когнітивних характеристиках старших офіцерів. Інтолерантність дає можливість диференціювати курсантів, сержантів і старших офіцерів за особистісними i стильовими характеристиками, а молодших офіцерів - тільки за стильовими характеристиками. Міжособистісна інтолерантність зумовлює біль- шою мірою відмінності в особистісних якостях курсантів, сержантів і старших офіцерів і в стильових характеристиках молодших офіцерів [10]. На взаємопов'язаності структурних компонентів (когнітивного, практично-поведінкового, емоційно-оцінного, аксіологічного, особистісного) толерантності військовослужбовців наголошує М. Фоміна. Критеріями зазначених компонентів вчена вважає такі: усвідомлення і інтеріоризацію ідей толерантної поведінки у професійній діяльності; розуміння і прийняття індивідуальності іншої людини; вміння курсанта проєктувати свою взаємодію як толерантну; оволодіння сукупністю різноманітних толерантних комунікативних умінь; вміння прощати іншим помилки, незручності, ненавмисно заподіяні неприємності; вміння пристосовуватися до характерів, звичок, установок і вподобань інших; вміння знаходити спільну мову 3 різними людьми в різних обставинах; використання опосередкованих методів і прийомів взаємодії; здатність залишатися самим собою; відсутність прагнення переробити, перевиховати іншого; терпимість до фізичного і психічного дискомфорту партнера, під якою розуміється вміння вислухати скарги, капризи, нервові випади тощо; встановлення рівноправних відносин; готовність прийти на допомогу іншим, чуйність, уважність, дбайливість у ставленні до людей; задоволеність системою міжособистісних відносин, що виникли; вміння приховувати і згладжувати неприємні почуття у разі зіткнення з неприємними якостями партнерів, до яких можна віднести грубість, хамство, самовпевненість тощо; відсутність яскраво виражених категоричності і консерватизму в оцінках людей; невикористання себе як еталону під час оцінки інших людей; повагу цінності прав і свобод людини; повагу рівноправності людей; визнання права вибору за іншими людьми власної життєвої позиції [21]. На основі аналізу зазначених матеріалів можна відзначити певну тотожність у критеріях, що виділяються науковцями. Зокрема, це усвідомленість знань про толерантність, вміння керувати своїми емоціями, толерантна поведінка. У Декларації принципів толерантності [5] розкриваються аспекти когнітивного, емоційного i поведінкового компонентів толерантності, де стверджується: «Толерантність - це правильне розуміння багатого різноманіття культур нашого світу, наших форм самовираження і способів прояву людської індивідуальності».

Ми погоджуємося зі слушними зауваженнями Г. Чуйко, Я. Чаплака [22, с. 36], які зазначають, що когнітивний, афективний і поведінковий компоненти толерантності можуть проявлятися різною мірою у різних життєвих ситуаціях. Додавання четвертого компонента можна сприймати як дроблення традиційних трьох компонентів, зі 
складників яких виділяється четвертий (наприклад, мотиваційний складник - 3 поведінкового, а ціннісний - 3 когнітивного та емоційного компонентів толерантності). Тобто навряд чи науково виправдано продовжувати дробити толерантність на складники аж до ентропії, щоб потім підсумувати, що це складний і комплексний феномен.

Враховуючи результати проведеного нами анкетування за авторською анкетою «Стан сформованості толерантності офіцера Національної гвардії України», орієнтуючись на змістовне наповнення психограми військовослужбовця НГУ [16] та проаналізувавши зміст компонентів толерантності різних видів діяльності, що характеризують дослідники, ми визначили такі компоненти та критерії структури толерантності майбутнього офіцера НГУ:

- когнітивний, який включає в себе такі елементи: рівень знань про толерантність та іiі види, про ненасилля та права людини, повноту та міцність знань, які необхідні для здійснення толерантного ставлення; виявлення зацікавленості до думки іншого, уваги до співрозмовника; усвідомлення сенсу толерантної взаємодії та готовності до неї; гнучкість мислення, здатність приймати різні точки зору, різні способи вирішення проблем, особливості сприйняття реальності, а також усвідомлення труднощів, планів, прийняття рішень;

- діяльнісний, який передбачає інтерес майбутніх офіцерів до формування толерантності, сформованість вмінь та навичок проєктувати свою взаємодію як толерантну та спонукання інших до такої поведінки, мотивацію до відповідальності за вибір життєвої позиції, володіння сукупністю толерантних комунікативних умінь, уміння пристосовуватись до інших людей та знаходити 3 ними спільну мову в різних обставинах, попри стереотипи. Діяльнісний компонент структури толерантності характеризується стратегією конструктивного самоствердження, умінням розв'язувати життєві проблеми, продуктивною активністю та креативністю, значною самоповагою та самовпевненістю, яка не набуває агресивності та демонстративності, високими вміннями у виборі адекватної та продуктивної лінії повсякденної поведінки, розумінням позиції та поглядів інших і дотриманням власної світоглядної зорієнтованості;

- емоційно-вольовий, який передбачає такі елементи: емоційну незалежність особистості i здатність ідентифікувати себе з іншою людиною; уміння уявляти себе на місці іншої людини і за необхідності надавати їй дійсну допомогу; продуктивність в незнайомій ситуації і у разі нестачі інформації уміння брати на себе відповідальність; прийняття рішень без довгих сумнівів і страху невдачі; толерантність до стресу, уміння управляти внутрішньою напругою в стресовій ситуації; організацію психологічних функцій під час виникнення непередбачуваних ситуацій i зростання втоми; прагнення до самовдосконалення, володіння вміннями самоконтролю, самоорганізації; емоційний відгук на іншу людину, іiі сприйняття; налаштованість у спілкуванні та побудові стосунків, а також у пошуку оптимальних шляхів толерантної взаємодії; толерантність до соціально-побутових незручностей.

Слід зазначити, що мотиваційно-смисловій сфері у структурі компонентів ми відводимо одне 3 найперших місць, проте ми не визначаємо іiі як окремий компонент, оскільки кожен із зазначених компонентів уміщує мотиваційні ознаки професійної самореалізації майбутнього офіцера НГУ. Досить слушною із цього приводу є думка Л. Анциферової, яка зазначає, що безперервне накопичення нових знань та вмінь, нових способів орієнтування у світі призводить до появи нових можливостей людини, нових психологічних здібностей. Переживання своїх збільшених можливостей, яке виникає при цьому, є мотиватором, рушійною силою особливої активності людини [2].

На основі названих критеріїв і показників схарактеризовано та визначено рівні сформованості толерантності майбутніх офіцерів НГУ. У дослідженні ми використовували традиційну шкалу, за якою рівні сформованості толерантності майбутніх офіцерів НГУ оцінювалися як високий, середній, низький. Наявність всіх ознак, властивих зазначеним показникам, характеризує високий рівень сформованості толерантності майбутніх офіцерів НГУ. Середній рівень характеризується наявністю лише половини чи трохи більше половини ознак відповідного критерію. Відсутність більшої частини зазначених ознак того чи іншого критерію вказує на низький рівень сформованості толерантності у майбутніх офіцерів НГУ.

Для визначення шляхів підвищення рівня розвитку толерантності майбутніх офіцерів НГУ необхідно розглянути процес іï формування, виявити те, які види діяльності і предмети мають суттєвий вплив на формування цієї якості. Загальними характеристиками будь-якого процесу $є$ суперечності (протиріччя), що лежать у його основі, етапи, рівні розвитку і умови протікання. Поняття «процес» означає послідовну зміну станів або явищ, яка відбувається закономірним порядком; хід розвитку чого-небудь [17, с. 343]. Крім того, слід зазначити, що розвиток толерантності офіцера полягає в переході від зовнішнього управління формуванням толерантності як особистісної якості до самоуправління, а від цього - до формування вказаної якості у підлеглих.

Ураховуючи рівні толерантності майбутнього офіцера НГУ, особливості процесу формування толерантності як професійно важливої його якості, 
що передбачає формування всіх типів толерантності (гендерна, міжособистісна, професійна, управлінська, політична тощо), необхідність у майбутньому формувати толерантність у своїх підлеглих, ми пропонуємо впроваджувати в освітній процес ВВНЗ формування толерантності майбутніх офіцерів за певними етапами. Назвемо ці етапи:

1) когнітивний етап спрямований на формування обізнаності курсантів щодо розуміння толерантності як соціальної цінності і норми сучасного суспільства, невід'ємної складової частини іміджу майбутньої діяльності в контексті усвідомлення ii значущості. Зазначений етап охопив перший та другий курси навчання курсантів та реалізувався шляхом застосування проблемної, проєктної, пошукової та дослідницької методик, що активізували пізнавальну діяльність курсантів. На даному етапі важливу роль виконує викладач та офіцер структурного підрозділу, який в освітньому процесі за рахунок власного прикладу, демонстрації толерантної взаємодії з тими, кого він навчає та виховує, активного впливу на свідомість курсантів сприяє формуванню у них толерантності та створенню толерантного освітнього середовища. 3 метою надання офіцерам структурних підрозділів та викладачам необхідних знань 3 теоpiї та методики формування толерантності і удосконалення сукупності певних вмінь та навичок запроваджено тренінг «Толерантна поведінка», що використовується на курсах підвищення кваліфікації науково-педагогічних і педагогічних працівників та в індивідуальній підготовці військовослужбовців НГУ, міжкафедральні семінари «Вплив толерантності на позицію реагування в конфліктах», «Критерії відмінності толерантної та інтолерантної особистості військовослужбовця НГУ». Під час проведення аудиторної роботи викладачі проводять короткі інформування про події в світі та Україні, висвітлюють такі події 3 позиції толерантності. У робочу навчальну програму «Військова психологія та педагогіка» запроваджено змістовий модуль «Толерантність у військовому середовищі». Обов'язки куратора навчальної групи доповнено принципами толерантності, які регулюють стосунки у взаємодії, a саме: спілкування на рівних, взаємна повага, доброзичливість і терпиме ставлення, відмова від насилля, свобода у думках, поглядах та висловлюваннях, співпраця і солідарність у вирішенні спільних проблем, відмова від негативних стереотипів. Обов'язковими є бесіди за такими темами: «Можливості толерантної поведінки у діяльності військовослужбовця», «Провокативна поведінка стосовно особистості військовослужбовця НГУ, засоби іiі нейтралізації», «Професійно важливі якості особистості військовослужбовця НГУ як умова забезпечення толерантної поведінки».
У плани виховної роботи НАНГУ запроваджено такі заходи, присвячені Дню толерантності: виготовлення та виставка плакатів від курсантських груп «Толерантність у нашому житті», конкурс серед курсантських підрозділів «Толерантність у висловах», тренінг «Гендерна толерантність». Для визначення рівнів сформованості когнітивного компонента толерантності майбутнього офіцера НГУ був використаний адаптований варіант методики Г. Бардіер «Види і компоненти толерантності і інтолерантності», для якісного аналізу аспектів толерантності - експрес-опитувальник «Індекс толерантності» (Г. Солдатова, О. Кравцова, О. Хухлаєв, Л. Шайгерова);

2) емоційно-вольовий етап спрямований на формування здатності особистісно сприймати себе, справлятися із власними емоціями, переживаннями i водночас спроможності адекватно сприймати i розуміти інших людей, володіти власною поведінкою у різних ситуаціях, здатності свідомо управляти своїми діями, станами і самопочуттям, витривалості до соціально-побутових незручностей, здібності продуктивно діяти в незнайомій ситуації і у разі нестачі інформації брати на себе відповідальність, приймати рішення без довгих сумнівів i страху невдачі. Зазначений етап реалізовувався за допомогою впровадження в освітній процес інтерактивних методів навчання та колізійних ситуацій і визначався методиками С. Баднера «Визначення толерантності до невизначеності», Є. Ейдмана «Вольовий самоконтроль», Л. Дерогатіса «Чи вмієте ви себе контролювати?». Емоційно-вольовий етап забезпечувався на основі дотримання таких принципів: принципу емоційності навчання, принципу індивідуалізації і диференціації навчання, принципу емоційно-вольової корекції, принципу спонукання до самовираження. Дотримання таких принципів сприяє створенню психологічно комфортного середовища освітнього процесу, взаємодії учасників, відкритості до співпраці, рівності аргументів;

3) діяльнісний етап передбачає формування навичок толерантної поведінки внаслідок практичних дій в системі міжособистісних відносин. На цьому етапі курсантів залучали до практичної професійної діяльності, тобто до практики та стажування, де їм потрібно було не тільки демонструвати толерантну взаємодію при виконанні службовобойової діяльності, а й навчати і виховувати у дусі толерантності підлеглий особовий склад. Так, у індивідуальних завданнях стажування та практики прописано, що потрібно провести 3 військовослужбовцями лекцію «Зміст поняття толерантності, iii типи та функції», бесіди «Толерантна поведінка військовослужбовця», «Толерантне військове середовище», організовувати проведення тренінгових вправ, що сприяють згуртуванню колективу 
військовослужбовців та впливають на толерантну взаємодію, провести діагностичні заходи 3 виявлення рівня толерантності та ії складників. Діяльнісний етап визначався системою вправ, задач i ситуацій та експертною оцінкою.

Описані етапи передбачають формування толерантності у процесі вивчення дисциплін гуманітарного характеру, спеціальних дисциплін, у процесі практики та стажування, у процесі позааудиторної діяльності, у процесі підготовки викладачів та офіцерів. У навчальному, виховному, практичному та службово-бойовому аспекті формування толерантності передбачає отримання знань про види, сутність і компоненти толерантності, можливість діагностики рівня особистої толерантності та інтолерантності, вправляння в толерантній взаємодії під час комунікативних дій, створення проблемних ситуацій та пошуку толерантних шляхів їх вирішення, участь у проведенні заходів толерантної спрямованості, відтворення рівня екстеріоризації формування толерантності в професійній діяльності. Процес формування толерантності у майбутніх офіцерів НГУ визначає впровадження в освітній процес різних видів діяльності творчого характеру, насичений зміст освітнього процесу такими знаннями, які максимально активізують пізнавальні інтереси, відповідають вимогам практичної діяльності та формують почуття відповідальності за оточення. Досягнення цієї мети можливе лише за умови створення толерантного освітнього сере- довища, що передбачає відмову від авторитарного догматизму, побудову освітнього процесу на основі суб'єкт-суб' єктних відносин, відкритості та відвертості діалогу, використання різноманітних форм діяльності на інтегративній основі і методів, що активізують мислення, уяву, пошукову діяльність.

Для ефективної реалізації зазначеного підготовлено методичні рекомендації «Формування толерантності у майбутніх офіцерів НГУ», у яких акумулюються матеріали для формування толерантності в освітньому процесі. Аналіз емпіричних даних засвідчив позитивну динаміку толерантності у майбутніх офіцерів НГУ у процесі професійної підготовки в експериментальній групі під час проходження зазначених етапів формування толерантності.

Висновки. Отже, дослідження толерантності як професійної якості майбутнього офіцера НГУ, визначення іiі структурних компонентів дозволило нам сформулювати модель процесу формування толерантності як професійної якості майбутнього офіцера НГУ у ВВНЗ й розробити етапи формування толерантності. Ці етапи включають проведення аудиторних та позааудиторних освітніх заходів, проведення 3 курсантами анкетування й тренінгів толерантності. Це визначає такі заходи як цілеспрямований поетапний процес формування професійно важливої якості майбутніх офіцерів під час навчання у ВВНЗ. Однак модель є структурним утворенням, відкритим для доповнень і змін.

\section{ЛIТЕРАТУРА}

1. Аніщенко В.О. Теоретичні і методичні засади ступеневої професійної підготовки офіцерів Державної кримінально-виконавчої служби України : дис. ... докт. пед. наук : 13.00.04 ; Національна академія Державної прикордонної служби України імені Богдана Хмельницького. Хмельницький, 2020. 515 с.

2. Анцыферова Л.И. К психологии личности как развивающейся системе. Психология формирования и развития личности / под ред. Л.И. Анцыферовой. Москва : Наука. 1981. С. 3-19.

3. Гнатовська К.С. Інформаційні технології як засіб формування толерантності в сучасному суспільстві. Освітні обрї. 2020. № 2 (51). С. 12-14.

4. Денисенко С.В. Формування адміністративно-управлінської культури майбутніх офіцерів Національної гвардії України у процесі професійної підготовки : дис. ... канд. пед. наук : 13.00 .04 ; Класичний приватний університет. Запоріжжя, 2018. 239 с.

5. Декларація принципів толерантності від 16.11.1995 № 995_503. URL: https://zakon.rada.gov.ua/laws/ show/995 503 (дата звернення: 04.07.2021).

6. Желясков В.Я. Теоретичні і методичні засади підготовки майбутніх судноводіїв у вищих морських навчальних закладах до професійної комунікативної взаємодії : дис. ... докт. пед. наук : 13.00.04 ; Національна академія Державної прикордонної служби України імені Богдана Хмельницького. Хмельницький, 2020. 544 с.

7. Звєрєва І.Д., Коваль Л.Г., Фролов П.Д. Діагностика моральної вихованості школярів : метод. посіб. Київ : ІСДО, 1995. 156 с.

8. Маркарян А.А. Педагогическое сопровождение развития толерантности в межличностном взаимодействии военнослужащих по призыву : автореф. дисс. ... канд. пед. наук : 13.00.01. Астрахань, $2010.25 \mathrm{c}$.

9. Монахов Н.И. Изучение эффективности воспитания: теория и методика: опыт экспериментального исследования : монография. Москва : Педагогика, 1981. 144 с.

10. Морозов А.А. Влияние толерантносты на принятие управленчиских решений военнослужащими : автореф. ... канд. псих. наук : 19.00.01. Минск, 2019. 30 с. 
11. Посохова Я.С. Толерантність у діяльності сучасного правоохоронця. Правоохоронна функиія держави: теоретико-методологічні та історико -правові проблеми : матеріали Міжнародної науково-практичної конференції. Харків : ХНУВС, 2015. С. 235-239.

12. Про Національну гвардію України : Закон України від 13.03 .2014 p. № 876-VII. URL: https://zakon.rada.gov.ua/laws/show/876-18 (дата звернення: 15.07.2021).

13. Про вищу освіту : Закон України від 01.07.2014 № 1556-VI. URL: https://zakon.rada.gov.ua/laws/ show/1556-18\#Text (дата звернення: 04.07.2021).

14. Про затвердження Положення про військові навчальні підрозділи закладів вищої освіти : сумісний наказ МОН України і МО України від 15.08.2018 р. № 910/412. URL: https://zakon.rada.gov.ua/laws/ show/z1229-18\#Техt (дата звернення: 04.07.2021).

15. Про затвердження стандарту вищої освіти за спеціальністю 253 «Військове управління» (за видами збройних сил) для першого рівня вищої освіти : Наказ МОН України від 29.10.2018 р. № 1168 / MOH України. URL: https://mon.gov.ua (дата звернення: 04.07.2021).

16. Приходько І.І., Мацегора Я.В., Колесніченко О.С., Юр'єва Н.В. Професіографія службово-бойової діяльності військовослужбовців Національної гвардії України : монографія. Харків : НАНГУ, 2017. 153 с.

17. Словник української мови : в 11т. / за ред. І.К. Білодіда. Київ : Наукова думка, 1970-1980. T. 7. C. 343.

18. Тробюк Н.Ю. Толерантність як професійно важлива якість майбутніх офіцерів Національної гвардії України. «Педагогіка формування творчої особистості у вищій $і$ загальноосвітній школах : Збірник наукових праць Класичного приватного університету. Запоріжжя : КПУ, 2020. № 70. С. 161-166.

19. Тробюк Н., Дем'янишин В., Гончар В. Формування толерантності майбутніх офіцерів Національної гвардії України як науково-педагогічна проблема. Молодь $і$ ринок. Дрогобицький державний педагогічний університет ім. І. Франка. 2019. Вип. № 10. С. 140-146.

20. Тушко К.Ю. Система підготовки майбутніх офіцерів Державної прикордонної служби України до професійної взаємодії : дис. ... докт. пед. наук : 13.00.04 ; Національна академія Державної прикордонної служби України імені Богдана Хмельницького, Хмельницький, 2020. 543 с.

21. Фомина М. Ф. Формирование толерантности курсантов военного вуза как фактора их профессиональной социализации. Вестник Адыгейского государственного университета. Серия «Педагогика и психология». 2009. Вып. 2 (44). С. 153-157.

22. Чуйко Г.В., Чаплак Я.В. Толерантність у житті людини і суспільства. Psychological Journal. 2020. Volume 6. Issue 2. C. 29-42.

\section{REFERENCES}

1. Anishhenko V.O. (2020) Teoretychni i metodychni zasady stupenevoji profesijnoji pidghotovky oficeriv Derzhavnoji kryminaljno-vykonavchoji sluzhby Ukrajiny [Theoretical and methodical bases of degree professional training of officers of the State penitentiary service of Ukraine] (PhD Thesis), Khmeljnycjkyj:Nacionaljna akademija Derzhavnoji prykordonnoji sluzhby Ukrajiny imeni Boghdana Khmeljnycjkogho [in Ukrainian]

2. Antsyferova L.I. (1981) K psikholohii lichnosti kak razvivaiushcheisia sistemy [To the psychology of personality as a developing system]. Psykholohiia formirovaniia i razvitiia lichnosti [Psychology of the formation and development of personality]. Moskva: Nauka. pp. 3-19.

3. Hnatovska K. S. (2020) Informatsiini tekhnolohii yak zasib formuvannia tolerantnosti v suchasnomu suspilstvi [Information technology as a means of forming tolerance in modern society]. Osvitni obrii, no. 2(51), pp. 12-14.

4. Denysenko Ye.V. (2018) Formuvannia administratyvno-upravlinskoi kultury maibutnikh ofitseriv Natsionalnoi hvardii Ukrainy u protsesi profesiinoi pidhotovky [Formation of administrative and managerial culture of future officers of the National Guard of Ukraine in the process of professional training] (PhD Thesis), Zaporizhzhia: Klasychnyi pryvatnyi universytet .

5. Deklaratsiia pryntsypiv tolerantnosti vid 16.11.1995 № 995503 [Declaration of the principles of tolerance: dated 16.11.1995 № 995_503]. Retrieved from: https://zakon.rada.gov.ua/laws/show/995_503 (accessed 18.07.2021).

6. Zheliaskov V.Ya. (2020) Teoretychni i metodychni zasady pidhotovky maibutnikh sudnovodiiv u vyshchykh morskykh navchalnykh zakladakh do profesiinoi komunikatyvnoi vzaiemodii [Theoretical and methodical bases of preparation of future pilots in higher sea educational establishments for professional communicative interaction] (PhD Thesis), Khmelnytskyi: Natsionalna akademiia Derzhavnoi prykordonnoi sluzhby Ukrainy imeni Bohdana Khmelnytskoho.

7. Zvierieva I.D., Koval L.H., Frolov P.D. (1995) Diahnostyka moralnoi vykhovanosti shkoliariv [Diagnosis of moral education of schoolchildren]. Kyiv : ISDO. [in Ukrainian]. 
8. Markarian A.A. (2010) Pedahohycheskoe soprovozhdenye razvytyia tolerantnosty v mezhlychnostnom vzaymodeistvyy voennosluzhashchykh po pryzыvu [Pedagogical support for the development of tolerance in interpersonal interaction of conscripts] (PhD Thesis), Astrakhan: Astrakhanskyj ghosudarstvennыj unyversytet.

9. Monakhov N.Y.(1981) Yzuchenye эffektyvnosty vospytanyia: teoryia y metodyka: opыt эksperymentalnoho yssledovanyia [Studying the effectiveness of education: theory and methodology: the experience of experimental research] Moskva : Pedahohyka. [in Russian].

10. Morozov A.A. (2019) Vlyianye tolerantnostы na pryniatye upravlenchyskykh reshenyi voennosluzhashchymy [Influence of tolerance on managerial decision-making by military personnel] ( $\mathrm{PhD}$ Thesis), Mynsk: Beloruskyj ghosudarstvennыj pedaghoghycheskyj unyversytet ymeny Maksyma Tanka.

11. Posokhova Ya.S. (2015) Tolerantnist u diialnosti suchasnoho pravookhorontsia [Tolerance in the activities of a modern law enforcement officer]. Proceedings of the Pravookhoronna funktsiia derzhavy: teoretykometodolohichni ta istoryko-pravovi problemy (Ukrajina, Kharkiv, 13 lystopada 2015) Kharkiv : KhNUVS, (pp. 235-239).

12. Pro Natsionalnu hvardiiu Ukrainy: Zakon Ukrainy (2014, march 13) No. 876-VII [On the National Guard of Ukraine: Law of Ukraine]. Retrieved from: https://zakon.rada.gov.ua/laws/show/876-18 (accessed 15.07.2021).

13. Pro vyshchu osvitu : Zakon Ukrainy (2014, July 01) No. 1556-VI [On higher education: Law of Ukraine]. Retrieved from: https://zakon.rada.gov.ua/laws/show/1556-18\#Text (accessed 04.07.2021).

14. Pro zatverdzhennia Polozhennia pro viiskovi navchalni pidrozdily zakladiv vyshchoi osvity: sumisnyi Nakaz MON Ukrainy i MO Ukrainy (2018, August 15) No. 910/412 [About approval of the Situation on military educational divisions of institutions of higher education: the joint Order of the Ministry of Education and Science of Ukraine and the Ministry of Defense of Ukraine]. Retrieved from: https://zakon. rada.gov.ua/laws/show/z1229-18\#Text (accessed 04.07.2021).

15. Pro zatverdzhennia standartu vyshchoi osvity za spetsialnistiu 253 «Viiskove upravlinnia» (za vydamy zbroinykh syl) dlia pershoho rivnia vyshchoi osvity: Nakaz MON Ukrainy (2018, October 29) No.1168 [On approval of the standard of higher education in the specialty 253 "Military Administration" (by type of armed forces) for the first level of higher education: Order of the Ministry of Education and Science of Ukraine] Retrieved from: https://mon.gov.ua (accessed 04.07.2021).

16. Prykhodko I. I., Matsehora Ya.V., Kolesnichenko O.S., Yurieva N.V. (2017) Profesiohrafiia sluzhbovoboiovoi diialnosti viiskovosluzhbovtsiv Natsionalnoi hvardii Ukrainy [Professiography of service and combat activity of servicemen of the National Guard of Ukraine]. Kharkiv : NANHU. [in Ukrainian].

17. Slovnyk ukrainskoi movy: v 11t. (1970-1980). [Dictionary of the Ukrainian language]. Compilers Bilodid I.K. Kyiv: Naukova dumka. tom. 7, pp. 343 [in Ukrainian].

18. Trobiuk N.Iu. (2020) Tolerantnist yak profesiino vazhlyva yakist maibutnikh ofitseriv Natsionalnoi hvardii Ukrainy [Tolerance as a professionally important quality of future officers of the National Guard of Ukraine]. Pedahohika formuvannia tvorchoï osobystosti u vyshchiy̆ i zahalnoosvitniy̆ shkolakh, vol. 4, no. 70, pp. 161-166.

19. Trobiuk N., Demianyshyn V., Honchar V. (2019) Formuvannia tolerantnosti maibutniikh ofitseriv Natsionalnoi hvardii Ukrainy yak naukovo-pedahohichna problema [Formation of tolerance of future officers of the National Guard of Ukraine as a scientific and pedagogical problem]. Molod i rynok, vol. 177, no. 10, pp. 140-146.

20. Tushko K.Yu. (2020) Systema pidhotovky maibutnikh ofitseriv Derzhavnoi prykordonnoi sluzhby Ukrainy do profesiinoi vzaiemodii [The system of training future officers of the State Border Guard Service of Ukraine for professional interaction] (PhD Thesis), Khmelnytskyi: Natsionalna akademiia Derzhavnoi prykordonnoi sluzhby Ukrainy imeni Bohdana Khmelnytskoho.

21. Fomina M.F. (2009). Formirovanie tolerantnosti kursantov voiennoho vuza kak faktora ikh professionalnoi sotsializatsii [Formation of tolerance of cadets of military high school as a factor of their professional socialization]. Vestnik Adyheiskoho hosudarstvennoho universyteta. Ser.: Pedahohika i psikholohiia, vol. 2, no. 44, pp. 153-157.

22. Chuiko H.V., Chaplak Ya.V. (2020) Tolerantnist u zhytti liudyny i suspilstva [Tolerance in human life and society]. Psychological Journal, vol. 6, no. 2, pp. 29-42. 